\title{
Surga Dan Neraka dalam Interpretasi Ibn ‘Arabi
}

\author{
Abd. Hamid \\ Jatim \\ STIU Al-Mujtama Pamekasan \\ e-mail: jamis.mr@gmail.com
}

\begin{abstract}
Abstrak: Hakikat surga dan neraka pada dasarnya masih masih memiliki beberapa interpretasi. Oleh karena itu penulis akan mengulas tuntas tentang ayat-ayat surga dan neraka, yaitu tala'ah terhadap ayat surga dan neraka perspektif Ibn 'Arabì yang difokuskan terhadap interpretasi Ibn 'Arabi terhadap Q.S al-Ra'dayat 35 dan alA'lā ayat 12-13 tentang makna surga dan neraka dengan penelitian kepustaan, adapun metode analisis data peneliti menggunakan deskriptif analitis. Tujuan penelitian ini adalah untuk mengetahui interpretasi Ibn'Arabi terhadap makna surga dan neraka. Hasil dari penilitian ini, Ibn 'Arabi mengatakan, surga adalah sebuah rumah kenikmatan yang semuanya kekal didalamnya. Surga itu dipenuhi dengan makanan, minuman, pernikahan, pakaian, pengharum, nyanyian yang merdu dan raut wajah yang berseri-seri dengan pemandangan yang dipenuhi dengan bidadari dan dikelilingi rindangnya pepohonan dan sungai yang mengalir jernih. Sedangkan Neraka menurut Ibn 'Arabi adalah tempat yang mana didalamnya masih disertai dengan kasih sayang Allah SWT. Seperti kesenangan atau kebahagiaan yang diumpamakan dengan orang yang bermimpi dalam tidurnya, hanya saja tidurnya tidak merubah tempat dimana dia berada, yaitu tetap didalam neraka.
\end{abstract}

Kata kunci: Surga, Neraka, Interpretasi, Ibn Arabi

Abstract: The nature of heaven and hell basically still has several interpretations. Therefore the author will review thoroughly about the verses of heaven and hell, namely the tala'ah of the verses of heaven and hell from the perspective of Ibn 'Arabi focused on Ibn' Arabi's interpretation of QS al-Ra'd verse 35 and al-A ' là verses 1213 about the meaning of heaven and hell with library research, as for the method of analyzing data researchers using descriptive analytical.

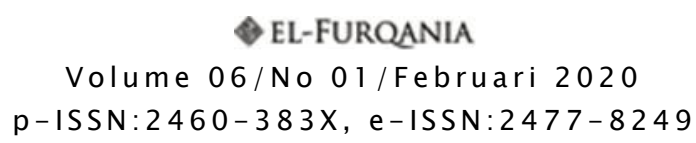


The purpose of this study is to find out Ibn'Arabi's interpretation of the meaning of heaven and hell. As a result of this research, Ibn 'Arabi said, heaven is a home of pleasure that is all eternal in it. Heaven is filled with food, drinks, weddings, clothes, fragrances, melodious singing and beaming faces with scenes filled with angels and surrounded by the shade of trees and clear flowing rivers. Whereas Hell according to Ibn 'Arabì is a place where in it is still accompanied by the love of Allah SWT. Like the pleasure or happiness that is likened to a person who dreams in his sleep, only his sleep does not change the place where he is, that is, remain in hell.

\section{Keywords: Heaven, Hell, Interpretation, Ibn Arabi}

\section{Prolog}

Surga adalah tempat yang di sediakan oleh Allah SWT yang penuh dengan kenikmatan. Sebagaimana firman Allah SWT dalam alQu'rān;

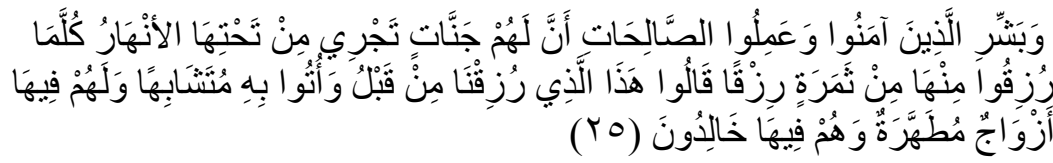
Artinya: "Dan sampaikanlah berita gembira kepada mereka yang beriman dan berbuat baik, bahwa bagi mereka disediakan surga-surga yang mengalir sungai-sungai di dalamnya. Setiap mereka diberi rezki buah-buahan dalam surga-surga itu, mereka mengatakan : "Inilah yang pernah diberikan kepada Kami dahulu." mereka diberi buahbuahan yang serupa dan untuk mereka di dalamnya ada isteri-isteri yang suci dan mereka kekal di dalamnya."(Q.S.al Baqarah 2: 25) ${ }^{1}$

Neraka adalah tempat penyiksaan bagi orang yang ketika didunia berbuat dosa kepada tuhan, neraka adalah tempat yang menyedihkan dan menyengsarakan. ${ }^{2}$

Neraka adalah tempat dimana didalamnya disediakan kobaran api yang menyala-nyala bagi hamba yang mendustakan Allah SWT dan melanggar setiap perintahnya. Sebagaimana firman Allah SWT dalam al-Qur'ān surah al-Furqān ayat 11-15 yang artinya "Dan disediakan api yang menyala-nyala bagi siapa yang mendustakan hari kiamat, Apabila neraka itu melihat mereka dari tempat yang jauh, mereka mendengar kegeramannya dan suara nyalanya. Dan apabila

\footnotetext{
${ }^{1}$ Departemen Agama RI, al-Qur'ān dan Terjemahannya, 12.

${ }^{2}$ Em Zul Fajri dan Ratu Aprilia Senja, Kamus Lengkap Bahasa Indonesia, 588.
} 
mereka dilemparkan ke tempat yang sempit di neraka itu dengan dibelenggu, mereka di sana mengharapkan kebinasaan akan dikatakan kepada mereka Jangan kamu sekalian mengharapkan satu kebinasaan, melainkan harapkanlah kebinasaan yang banyak, Katakanlah: Apa ('adhāb) yang demikian itukah yang baik, atau surga yang kekal yang telah dijanjikan kepada orang-orang yang bertaqwa? dia menjadi balasan dan tempat kembali bagi mereka. ${ }^{3}$

Salah satu temuan yang penulis dapatkan adalah sebuah skripsi karya Muhammad Yudi Ashari yang berjudul Kosep kekekalan Surga dan Neraka Dalam al-Qur'ān. Dalam skripsi ini penulis mengulas tentang ayat- ayat yang menjelaskan tentang kekekalan surga dan neraka. Dari telaah pustaka ini, penulis tidak menemukan pemikiran Ibn 'Arabi terkait dengan ayat-ayat surga dan neraka, sehingga mendorong penulis untuk mengkaji permasalahan yang telah ditetapkan di atas yang berjudul "Makna Surga Dan Neraka dalam al-Qur'ān perspektif Ibn 'Arabì (Analisis terhadap ayat- ayat surga dan neraka dalam Q.S al-Ra'd ayat 35 dan Q.S alA'lā ayat $12-13$

Dalam penafsirannya Ibn 'Arabī berpendapat: Khusus untuk surga, hal ini menunjukkan bahwa keabadian adalah merupakan sifat khusus untuk surga. Sedangkan siksa neraka tidak abadi.Ibn 'Arabì menyatakan kalau tidak ada tambahan tiga ayat yang berkenaan dengan surga itu, niscaya bisa dipahami bahwa surgapun tidak abadi di akhirat kelak. Menurut Ibn 'Arabì , pada saatnya manusia akan bebas dari siksaan, bahkan mersakan kenikmatan, meski sesungguhnya kenikmatan itu sama sekali tidak bisa dibandingkan dengan yang dialami para penghuni surga. ${ }^{4}$

Oleh karena itu penulis akan mengulas tuntas tentang ayatayat surga dan neraka, perspektif Ibn 'Arabì yang difokuskan terhadap surah al-Ra'd ayat 35 dan al- A'lā ayat 12-13.

\section{Ibn Arabi dan Pemikirannya}

Nama lengkap Ibn 'Arabì adalah Muhammad bin 'Ali bin Ahmad bin 'Abdullāh Ath-Thā'i Al-Haitamī. Ia lahir di Murcia, Andalusia Tenggara, Spanyol, tahun $560 \mathrm{H}$, dari keluarga berpangkat,

\footnotetext{
${ }^{3}$ Al-Qur'ān. 25:11-15.

${ }^{4}$ Muhyiddin Ibn 'Arabī, Rahmatun min al-Rahmān fì Tafsìri wa Isyā̄at al-Qur'ān, jilid 3, (Kairo: Dār al-Kutūb al-Ilmiyah,1989),3.
} 
hartawan, dan ilmuwan. ${ }^{5}$ Pada tahun $620 \mathrm{H}$ ia tinggal di hijaz dan meninggal di sana pada tahun $638 \mathrm{H}$. namanya biasa di sebut tanpa"al" untuk membedakan dengan Abū Bakar Ibn Al- Arabī, seorang qadi dari sevilla yang wafat tahun $543 \mathrm{H}$. Di sevilla (spanyol), ia mempelajari Al-Qur'ān, hadith serta fiqih pada sejumlah murid seorang faqih Andalusia terkenal, yakni Ibn Hazm al-Zahiri. ${ }^{6}$

Setelah berusia 30 tahun, ia mulai berkelana ke berbagai kawasan Andalusia dan kawasan Islam bagian barat. Di antara deretan guru-gurunya, tercatat nama-nama seperti Abū Madyān AlGaw̄th al-Talimsari. ${ }^{7}$ Yasmin Mushaniyah(seorang wali dari kalangan wanita). Keduanya banyak mempengaruhi ajaran-ajaran Ibn 'Arabi. Dikabarkan ia pun pernah berjumpa dengan Ibn Rushd, filosof muslim dan tabib istana dinasti Barbar dari Alomohad, di Kordova. ${ }^{8}$ Dia dikabarkan mengunjungi al-Mariyah yang menjadi pusat madrasah Ibn Masarrah, seorang sufi filsafat yang cukup berpengaruh dan memperoleh banyak pengaruh di Andalusia.

Secara tipikal Ibn 'Arabi dianggap sebagai seorang sufi. Dan anggapan ini relatif benar jika kita memahami istilah sufisme untuk menunjuk pada tambatan pemikiran dan Praktek Islam yang menekankan pada pengalaman langsung dari obyek-obyek iman. Terlepas dari perbedaan mengenai asal-usul kata yang membentuk artinya seperti safa (suci), shaf (baris) suffah (penghuni masjid nabawi): Sophia (hikmah), atau suf (bulu domba) - Tasawuf mengandung makna yang dalam yang merujuk pada kebersihan batin, mendekatkan diri pada Tuhan, menjauhkan diri dari kesombongan dan ketamakan terhadap daya tarik dunia. Tasawuf secara umum adalah falsafah hidup dan cara tertentu dalam tingkah laku manusia dalam upaya merealisasikan kesempurnaan moral, pemahaman hakikat realitas dan kebahagian rohaniah.

Adapun ajaran sentral Ibn 'Arabiadalah waḥdat al-Wujūd (kesatuan wujud). Meskipun demikian,istilah ini tidaklah berasal dari beliau tapi berasal dari Ibn Taimiyah. Tokoh yang paling keras dalam mengecam dan mengkritik ajaran tersebut, Ibn Taimiyah yang telah berjasa dalam memopulerkannya ke tengah masyarakat islam. ${ }^{9}$

\footnotetext{
${ }^{5}$ M. Solihin dan Rosihon Anwar, IImu Tasawuf, (bandung: pustaka setia), 174, TTh.

${ }^{6}$ Ibid, 175.

${ }^{7}$ Ibid., 175.

${ }^{8}$ Ibid., 175.

${ }^{9}$ M. Solihin dan Rosihon Anwar, Ilmu Tasawuf, 176
} 
Disebutkan dalam El-Furqania, Abdul Ghani al- Nablusī mengatakan bahwa tentang hubungan antara pencipta dan ciptaan, dari sudut pandang rasional dan intuitif kebanyakannya mengikuti pandangan-pandangan Ibn 'Arabì.Dalam mengelaborasi metafisik dari sudut pandang tasawuf, Ibn 'Arabi adalah yang paling detail. Sebagaimana diketahui, hunbungan sang pencipta dengan ciptaan bias dikenal dengan istilah tanazzul dan taraqqi. ${ }^{10}$

Tanazzul adalah dalam konteks tajalliwa ta 'ayyun sang pencipta kepada ciptaannya. Dengan kata lain, sangpencipta menampakkan ayat-ayatnya kepada hamba -hambanya sesuai level dan martabat sang hamba. ${ }^{11}$

Taraqqi adalah kembalinya sang hamba kepada sang khāliq. Dengan kata lain, ketika manusia lebih tinggi mencapai derajat dan martabat dengan cara ihsān, maka dia akan berjumpa dengan tajalliyăt dan ta'ayunät Allah SWT. Jika seseorang mampu mencapai derajat itu, maka dia akan mampu melihat hakikat segala sesuatu dengan pengamatan langsung dan pencapaian informasi yang lebih akurat. ${ }^{12}$

Disamping itu, meskipun semua orang sepakat menggunakan istilah Wahdat al-Wujūd untuk menyebut ajaran sentral Ibn 'Arabi, mereka berbeda pendapat dalam memformulasikan pengertian Waḥdat al-Wujūd. Menurut Ibn 'Arabī, wujud semua yang ada ini hanya satu dan wujud makhluk pada hakikatnya adalah wujud khaliq pula. Tidak ada perbedaan antara keduanya dari segi hakikat. Adapun kalau ada yang mengira antara wujud sang khäliq dan makhluk ada perbedaan, hal itu dilihat dari sudut pandang pancaindra lahir dan akal yang terbatas kemampuannya dalam menangkap hakikat apa yang ada pada dhat-nya dari kesatuan dhātiah yang segala sesuatu berhimpun padanya. ${ }^{13}$

\section{Tinjauan Terminologis Surga dan Neraka dalam al-Qur'ān}

Dalam al-Qur'ān surga memiliki banyak nama ditinjau dari sifat-sifatnya. Menurut bahasa Surga adalah sebuah kenikmatan atau

\footnotetext{
${ }^{10}$ Akhmad Rofii Damyati dkk, "El-Furqania jurnal Ushuluddin dan Ilmu-Ilmu keislaman”, STIU :Al-Mujtama' Pamekasan, Vol. 001 No. 01(Agustus,2015),22.

${ }^{11}$ Ibid., 22.

${ }^{12}$ Ibid., 22.

13 Akhmad Rofii Damyati dkk, "El-Furqania jurnal Ushuluddin dan Ilmu-Ilmu keislaman”, 176.
} 
tempat yang dipenuhi nikmat. ${ }^{14}$ Surga menurut bahasa bersal dari kata jannah yang berarti taman yang terdiri dari pohon- pohon kurma atau pohon-pohon lain. ${ }^{15}$ Adapun secara istilah surga adalah keutamaan dari Allah SWT kepada setiap hambanya yang bertauhid dan tidak melakukan kesyirikan. ${ }^{16}$ Surga adalah tempat di alam akhirat yang membahagiakan(penuh kesenangan)sebagai balasan orang-orang yang beriman. ${ }^{17}$ Surga juga bisa diartikan sebagai suatu tempat kediaman yang disediakan Allah SWT untuk hambanya yang bertaqwa kepadanya, sebagai balasan kepada mereka atas keimanannya yang jujur dan benar serta amal perbuatannya yang șāleh. ${ }^{18}$

Surga bersal dari bahasa 'Arāb al-Jannah yang berarti taman atau kebun. ${ }^{19}$ Hal ini berdasarkan atas pengertian dalam al-Qur'ān yang artinya: Sesungguhnya bagi kaum saba ada tanda(kekuasaan tuhan) ditempat kediaman mereka yaitu dua buah kebun(al-Jannah) disebelah kanan dan sebelah kiri(kepada mereka dikatakan).

Setelah Allah SWT membangkitkan makhluk untuk memasuki hari perhitungan, mereka akan digiring menuju tanah mahsyār. Disana Allah SWT akan memutuskan hukuman, menimbang amal perbuatan mereka, serta memberikan balasan kepada setiap manusia sesui dengan perbuatannya, apakah dia termasuk penghuni Surga atau Neraka. ${ }^{20}$

Secara bahasaNeraka bisa bermakna haram, jahannam dan kafir. ${ }^{21}$ Secara istilah Neraka adalah tempat penyiksaan bagi orang yang ketika didunia berbuat dosa kepada tuhan, Neraka adalah tempat yang menyedihkan dan menyengsarakan. ${ }^{22}$

Menurut Ibn 'ArabiNeraka berarti Dār al-Gab artinya tempat yang penuh dengan amarah. ${ }^{23}$ beliau membagi neraka menjadi dua bagian yaitu Nar Allāh(neraka Allah) dan Nār al-Lahab (api yang

\footnotetext{
${ }^{14}$ Ibn Manzūur, Lisān al-Arāb, Vol 4,(Beirut: Dar Sadir), 440, TTh.

${ }^{15}$ Ahsin W. Alhafidz, Kamus Ilmu Al-Qur'ān(Jakarta: amzah, 2008), 136.

${ }^{16}$ Sayyid Abd al-Rahman, Durūs al 'Aqāid al Diniaatì, tt, 46.

${ }^{17}$ Em Zul Fajri dan Ratu Aprilia Senja, Kamus Lengkap Bahasa Indonesia, 544.

${ }^{18}$ Ahsin W. Alhafidz, Kamus Ilmu al-Qur'ān, 136.

${ }^{19}$ Deddy Ilyas, "Antara surga dan neraka menanti kehidupan", 2 (Desember, 2013), 168

${ }^{20}$ Manshur Abdul Hakim,Kiamat (Jakarta:Gema insane, 2006), 216.

${ }^{21}$ Hasin ibn Muhammad, Kamus al-Qur'ān au Islāh al-Wujūh wa al-Nadhāirfī alQur'ān al-Karìm, (Bairut: Dār al-'Ilmi, 1085), 468.

${ }^{22}$ Em Zul Fajri dan Ratu Aprilia Senja, Kamus Lengkap Bahasa Indonesia, 588.

${ }^{23}$ Iskandar Arnel dan Muhammad Yasir, "Urgensi al-Nār dalam perspektif tashawuf Ibn 'Arabī dalam kehidupan insān', Jurnal uṣūluddìn, 23 (Juni, 2015), 92
} 
Surga Dan Neraka dalam Interpretasi Ibn 'Arabi

menyala-nyala ${ }^{24}$ Secara istilah dalam perspektif Ibn 'ArabīNär Allāh adalah neraka yang bersifat batin, beliau juga menyebut Neraka ini dengan Nār al-Wujūd yaitu Neraka yang senantiasa mengiringi keberadaan setiap orang. ${ }^{25}$

Menurut bahasa al-Nār artinya api. ${ }^{26}$ secara istilah al-Nār adalah Neraka, yaitu tempat penyiksaan atau hukuman dimana bentuk hukuman yang paling sangat menyiksa ini digambarkan sebagai api, yaitu api neraka yang bahan bakrnya batu dan manusia. ${ }^{27}$ Perlu diketahui bahwa dalam al- Qur'ān terdapat dua istilah lain yang digunakan sebagai sinonim kata al-När. Pertama adalah istilah dār al- bawār disebutkan hanya sekali dalam surah Ibrāhim 14:18, kedua adalah Jahannam suatu istilah yang disebutkan sebanyak 77 kali dalam 77 ayat-ayat al-Qur'ān yang dalam 9 ayat didapati bergandeng dengan al-Nār sehingga menjadi Nār Jahannam. ${ }^{28}$ (Nār) yaituNeraka,secara bahasa ialah kobaran api sedangkan (al-Lahab) yaitu yang panas dan bersifat membakar. Allah SWTberfirman daląm al-Qur'ān;

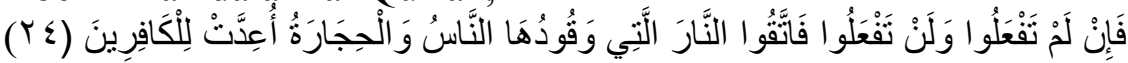
"Jika kamu tidak mampu membuat, dan (pasti) tidak akan mampu, maka takutlah kamu akan api neraka yang bahan bakarnya manusia dan batu yang disediakan bagi orang-orang kafir".(Q.S. Al Baqarah2: $24){ }^{29}$

\section{Interpretasi Ibn Arabi Surah al-Ra'd ayat 35 dan al-A'lā ayat 12-13}

\section{Q.S al-Ra'd ayat 35}

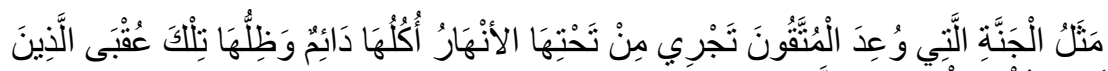

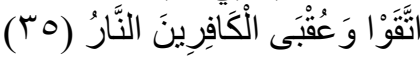

"Perumpamaan syurga yang dijanjikan kepada orang-orang yang takwa ialah (seperti taman);

mengalir sungai-sungai di dalamnya; buahnya tak henti-henti sedang naungannya (demikian pula). Itulah tempat kesudahan bagi

${ }^{24}$ Ibid

${ }^{25}$ Ibid

${ }^{26}$ Ahsin W. Alhafidz, Kamus Ilmu Al-Qur'ān(Jakarta: amzah, 2008), 219.

${ }^{27}$ Ibid

${ }^{28}$ Iskandar Arnel dan Muhammad Yasir, "Urgensi al-Nār dalam perspektif tashawuf Ibn 'Arabi”', 92

${ }^{29}$ Al-Qur'ān, 2:24. 
orang-orang yang bertakwa, sedang tempat kesudahan bagi orangorang kafir ialah neraka." (Al-Ra'd 13: 35). ${ }^{30}$

Dalam ayat ini Ibn 'Arabi menafsirkan bahwa surga yang dijanjikan terhadap orang-orang yang bertakwa kepadanya.Surga yang dijanjikan yaitu surga yang didalamnya terdapat sungai-sungai yang mengalir dan juga terdapat makanan dan tempat teduh yang semua kekal adanya. karena sesungguhnya akhirat itu tempat yang kekal dan didalam kekekalannya semua manusia makan dan tidak berpuasa, dan ahli surgapun sarapannya dengan berbagai sesuatu yang enak dan sarapan tersebut juga kekal dan makanannya pun juga kekal dan tidak terput us put us karena kekekalannya itu adalah sesuatu yang sangat nikmat. Makanan yang terdapat didalamnya sangat baik buat badan.Maka dari itu ahli surga makan dan minum, dan mereka makan dan minum bukan karena kelaparan melainkan karena syahwat.Karena sesungguhnya ahli surga mengetahuinya bahwa inilah saatnya kenikmatan yang patut diperoleh. ${ }^{31}$

Semua kenikmatan dalam surga setiap pagi dan sore tidak pernah berubah dan tidak pernah berkurang.Kesenangan dan kenikmatan didalam surga tidak harus dicari karena berbeda dengan keadaan ahli neraka dimana ahli neraka sangat kelaparan dan kehausan juga kesakitan.Dengan demikian surga itu adalah sebuah rumah kenikmatan yang semuanya kekal didalamnya, ahli surgapun biasa diumpamakan dengan orang yang berbuka puasa dimana mereka tau bahwa pada saat itu sudah saatnya menikmati semua hidangan yang tersedia dengan syahwatnya. ${ }^{32}$

Surga itu dipenuhi dengan makanan, minuman, pernikahan, pakaian, pengharum, nyanyian yang merdu dan raut wajah yang berseri-seri dengan pemandangan yang dipenuhi dengan bidadari dan dikelilingi ridangnya pepohonan dan sungai yang mengalir jernih. ${ }^{33}$

Dilihat dari interpretasi Ibn 'Arabì, beliau memaknai surga sebagai tempat yang kekal dan semuanya kekal didalamnya.Surga adalah gudang kenikmatan yang patut diperoleh oleh hamba yang taqwa kepada Allah SWT. Disamping itu beliau memaknai surga

\footnotetext{
${ }^{30}$ Al-Qur'ān, 13: 35.

${ }^{31}$ Muhyiddin Ibn 'Arabi, Raḥmatun min al-Roḥmān fí Tafsīi wa Isyārah al-Qur'ān, jilid 3, (Kairo: Dar al-Kutub al-Ilmiyah,1989), 424.

${ }^{32}$ Ibid

${ }^{33}$ Muhyiddin Ibn 'Arabi, al-Futuhät al-Makkiyah ( university of toronto library, 1852), 353.
} 
sebagai tempat kesenangan dan kebahagiaan yang membuat penghuni surga betah didalamnya.Tidak hanya itu, pengarang kitab al-Futuhät al-Makkiyah ini menyebutkan dalam kitabnya bahwa surga itu dimaknai sebagai tempat yang dilengkapi dengan berbagai jamuan atau hidangan mulai dari makanan, minuman, pakaian, pengharum, nyanyian yang merdu dan raut wajah yang berseri- seri. Dan beliau juga memaknai surga sebagaisebuah tempat yang dilengkapi dengan pemandangan pohon yang rindang dan sungai yang mengalir jernih serta dipenuhi dengan bidadari.

\section{Q.S al-A'lā ayat $12-13$}

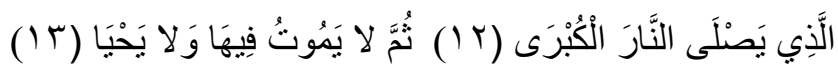

"12. (yaitu) orang yang akan memasuki api yang

besar (neraka), 13. kemudian Dia tidak akan mati di dalamnya dan tidak (pula) hidup." (Q.S. al-A'lā 87:12-13) ${ }^{34}$

Dalam ayat ini Ibn 'Arabīmemaknai bahwasannya keadaan ahli neraka atau penghuni neraka seperti halnya orang yang tidur dimana mereka tidak mati pula tidak hidup. ahli neraka juga mempunyai kesenananganseperti halnya orang yang sedang tidur dengan disertai oleh mimpi tapi Ibn 'Arabimenyebutkan bahwasanya kenikmatan yang dialami tersebut yaitu tetap berada di dalam neraka. Ahli neraka tidak bangun-bangun dari tidurnya maka munurut Ibnu 'Arabīitulah bentuk dari kasih sayang allah terhadap ahli neraka. ${ }^{35}$

Dalam hal ini Ibn 'Arabimengumpamakan terhadap ahli neraka yaitu seperti halnya orang yang sedang kepanasan dan diberi sesuatu yang sangat dingin.Dalam hal ini kita bisa analogikan dengan ketika kita sedang kepanasan dan diberi sesuatu yang dingin seperti es dan sebagainya seperti es dan sebagainya tentu kita bisa bayangkan betapa bahagianya kita.Ibn 'Arabijuga berpendapat bahwa kenikmatan yang kekal yang dirasakan oleh ahli neraka yaitu seperti halnya orang yang tidur dimana mereka diselimuti mimpi yang indah.Dalam hal ini Ibn 'Arabi menyebutkan bahwasannya orang yang tidur terkadang terbaring dengan keadaan yang sakit dan penuh dengan keputus asaan, ada juga dimana orang tidur tersebut melihat

\footnotetext{
${ }^{34}$ Al-Qur'ān, 87: 591.

${ }^{35}$ Muhyiddin Ibn 'Arabì, Raḥmatun min al-Raḥmān fí Tafsìni wa Isyārah al Qur'ān, jilid 3, 485 .
} 
dirinya bagaikan seorang raja yang mempunyai kekayaan dan kekuasaan. ${ }^{36}$

Kekuasaan adalah kekuatan atau kemampuan. ${ }^{37}$ Dan kesenangan tersebut jelas adanya.Tapi disini keadaan tidurnya tetap dalam siksaan dan siksaan tersebut tidak pernah lepas dari ahli neraka, karena siksaan tersebut tetap menimpa mereka sampai rahmat Allah SWT datang. Hal ini sama dengan perumpamaan seorang yang hendak di oprasi dimana sebelum dilaksanakan oprasi seorang pasien di bius terlebih dahulu sehingga tidak ada rasa sakit sedikitpun. Begitu juga dengan ahli neraka yang hendak disiksa dimana kemudian karena mendapat rahmat Allah SWT mereka seakan tidak mati pula tidak hidup. ${ }^{38}$

Adapun neraka, Ibn 'Arabì memaknai sebagai tempat yang mana didalamnya masih disertai dengan kasih sayang Allah SWT.Oleh karena itu penghuni neraka diumpamakan dengan orang yang tidur dimana mereka tidak hidup dan tidak mati.Beliau juga berpendapat bahwa dineraka terdapat kesenangan atau kebahagiaan yang diumpamakan dengan orang yang bermimpi dalam tidurnya, hanya saja tidurnya tidak merubah tempat dimana dia berada, yaitu tetap didalam neraka.

Pertama tentang kasih sayang Allah SWT yang mana beliau memaknainya bahwa didalam neraka terdapat kasih sayang Allah SWT, sehingga penghuni neraka diumpamakan dengan orang yang tidur yang disertai dengan mimpi, itupun disebabkan adanya kasih sayang Allah SWT terhadap penghuni neraka.

Kedua tentang mimpi yang mana beliau meyebutkan bahwa mimpi yang dialami oleh penghuni neraka yaitu terkadang terlihat seperti orang yang tidur terbaring dengan keadaan yang sakit dan penuh keputus asaan, maka mimpi yang dihasilkannya pun dengan raut wajah yang menakitkan atau menyedihkan. Begitupun sebaliknya penghuni neraka terkadang terlihat seperti orang yang tidur dengan bermimpi dirinya bagaikan seorang raja yang mempunyai kekayaan dan kekuasaan, maka raut wajah yang dihasilkan yaitu dengan senyuman, tentu itu semua tidak lain bentuk kasih sayang Allah SWT masih ada didalam neraka.

\footnotetext{
${ }^{36}$ Muhyiddin Ibn 'Arabī, Rahmatun min al-Rahmān, 485.

${ }^{37}$ Em zul fajri dan Rtu Aprilia Senja, Kamus Lengkap Bahasa Indonesia, 493.

${ }^{38}$ Muhyiddin Ibn 'Arabi, Raḥmatun min al-Raḥmān fì Tafsīi wa Isyārah al Qur'ān, jilid 3, 485.
} 
Ketiga yaitu tentang tempat tidur yang disertai mimpi yaitu beliau menetapkan bahwasannya tetap berda didalam neraka. Yang mana pengarang kitab al-Futhăt al-Makkiyah ini dalam kitabnya memaknai neraka sebagai penjara atau tahanan yang didalamnya menjadi sarang berbagai penyakit, dan beliau juga menyebutkan bahwa neraka dipenuhi dengan makanan yang terbuat dari hati hitamnya hewan yang hidup di gunung yang terbuat dari darah yang kental yang mengandung penyakit sehingga membuat ahli neraka merasa kesakitan. ${ }^{39}$

Munasabah ayat: diantara keduanya yaitu sama-sama termasuk suratMakkiyah, yang mana surat Makkiyah adalah surat yang turun di makkah atau turun sebelum nabi Muhammad SAW. Hijrah.Adapun hubungan kedua ayat ini yaitu dilihat dari makna Surga dan Neraka itu sendiri, Yang mana keduanya adalah suatu tempat yang sama-sama berada di dalam akhirat, yang keduanya menjadi bentuk dari manifestasi Allah SWT.Terhadap semua makhluknya. Yaitu makhluk yang berperilaku baik(Protagonis) akan mendapat jaminan surga, sedangkan makhluk yang berperilaku tidak baik atau jahat(Antagonis) maka akan dapat jaminan neraka.

Dalam pemaknaan surga, Ibnu Arabi tidak jauh berbeda dengan mufassir pada umumnyayang memaknai surga, yaitu sebagai tempat yang memiliki sungai-sungai yang mengalir di dalamnya.Dan semua yang ada di dalamnya, seperti buah-buahan, makanan beserta minuman yang tidah pernah putus-putus dan kekal. Seperti penafsiran dari al-Zuhaili dalam kitabnya yang memaknai surga sebagai tempat yang di dalamnya terdapat sungai-sungai yang mengalir diberbagai penjuru dan sisinya. Dimanapun para penghuninya berada, disana pula mereka mendapati sungai-sungai yang mengalir.Mereka mengalirkan sungai-sungai sekehendak mereka dan mengarahkannya kemana saja mereka. Dan apa yang dikonsumsi di dalamnya berupa buah-buahan, makanan dan minuman tidak pernah putus dan tidak pernah ada habisnya. Demikian pula dengan naungannya, senantiasa ada, tidak pernah terhapus dan hilang. ${ }^{40}$

Begitu pula dengan pendapat Ibn Kathïr yang menyebutkan dalam kitabnya yaitu dengan memaknai surga sebagai tempat yang mana didalamnya terdapat buah-buahan, makanan dan minuman yang

\footnotetext{
${ }^{39}$ Muhyiddin Ibn 'Arabi, al-Futuhàt al-makkiyah,353.

40 Wahbah al-Zuhaili, al-Tafsiral-Munir, terj. Abdul Hayyie (Jakarta: Gema Insani, 2015), 179-180.
} 
tiada henti dan tidak binasa.Demikian juga dengan naungannya yang tidak hilang atau habis. ${ }^{41}$

Sedangkan al-Qurtūbi juga berpendapat dalam kitabnya yang menyebutkan bahwa makna Surga yaitu sebuah tempat yang di dalamnya terdapat sungai-sungai yang mengalir beserta makanannya yang tidak putus-putus dan naungannya yang tidak pernah hilang. ${ }^{42}$ al-Tabāri dalam kitabnya yang menaknai surga sebagai tempat yang di dalamnya terdapat sungai sungai yang mengalir dan yang dimakan darinya tidak akan hilang dan tidak akan lenyap begitu pula dengan naungannya. ${ }^{43}$

Adapun dalam pemaknaan neraka, ada beberapa mufassir yang berbeda pendapat, diantaranya Ibn Kathir, al-Qurtūbì dan hamka, yang mana pendapat Ibn 'Arabi terhadap makna neraka, yang di dalam neraka para penghuninyamemiliki kebahagiaantidak mati dan pula tidak hidup bagaikan orang yang tidur dengan disertai mimpi.Dan penghuni neraka juga diumpamakan seperti halnya orang yang sedang kepanasan kemudian diberi sesuatu yang dingin tentu kita bisa bayangkan betapa bahagianya mereka. Tetapi hal itu dibantah oleh Hamka bahwasanya orang kalau terlalu dingin juga mati. Disebutkan dalam kitabnya yaitu keadaan ahli neraka akan merana. Tidak akan mati, sebab mati hanya sekali saja, yaitu ketika hari perpindahan dari alam fana', dunia kepada alam akhirat.Padahal di dunia ini banyaklah mati terlepas dan sengsara karena sakit telah sampai dipuncak(sakarātul maūt). Terlalu sakit orangpun mati, terlalu panas juga mati, terlalu dingin juga mati dan terlalu susah juga mati. Hamka juga menyebutkan bahwasanya di dalam neraka tidaklahakan terlepas dari sengsara adhab. Karena mati tidak ada di sana. Dan tidak pula hidup, karena hidup yang berarti di akhirat itu ialah di dalam surga dengan segala nikmat yang telah disediakan Allah SWTbagi hamba-hambanya. ${ }^{44}$

Meskipun ada berbagai mufassir yang tidak sepaham dengan Ibn 'Arabi, tapi ada juga salah satu mufassir yang sepaham dengannya meskipun tidak terurai panjang seperti yang beliau

${ }^{41}$ Ibnu kathïr, Lubāb al-Tafsīr min Ibn Kathīr, terj. M.Abdul Gaffar (Jakarta: pustaka imam asy-syafi'I, 2008), 48-49.

${ }^{42}$ Al-Qurtūbì, al-Jāmi li Ahkām al-Qur'ān, terj. Muhyiddin Masridha (Jakarta: pustaka azzam, 2008), 767.

${ }^{43}$ Al-Tabarì, Jamì' al-Bayān an Ta'wìl ay al-Qur'ān, terj. Misbah (Jakarta: pustaka azzam, 2009), 358.

${ }^{44}$ Hamka, Juz 'Amma Tafsir al-Azhār, (Jakarta: Gema Insani, 2015), 187. 
jelaskan. Yaitu seperti al-Zuhaili dalam kitabnya yang menyebutkan bahwa di dalam neraka itu para penghuninya tidak mati sehingga dapat beristirahat dari siksanya, dia juga hidup sehingga dapat hidup dengan baik, tenang dan bahagia. ${ }^{45}$

\section{Makna surga dan neraka menurut Ibn 'Arabī}

\section{Makna surga dalam al-Qur'ān}

Kata al-Jannah biasa menunjuk pada pengertian taman atau kebun, ini berdasarkan pengertian yang terkandung dalam al-Qur'ān sebagai berikut: sesungguhnya bagi kaum saba' ada tanda(kekuasaan tuhan)ditempat kediaman mereka yaitu dua buah kebun(jannatan)disebelah kanan dan disebelah kiri.(kepada mereka dikatakan). ${ }^{46}$

Secara ringkas kata al-jannah umumnya mengandung berbagai jenis pepohonan yang lebat berdahan dan berjuntaian, ${ }^{47}$ adapun secara khusus kata al-jannah menunjuk pada tempat yang dipenuhi nikmat. ${ }^{48}$

Dalam al-Qur'ān, kataal-Jannah dan ragam perubahan bentuknya terulang sebanyak 144 kali.Dalam al-Qur'ān kata alJannahdipakai untuk menunjuk tempat kediaman orang-orang mukmin di alam akhirat. Demikian juga disebutkan dalam al-Qur'ān beberapa ciri yang dimiliki oleh surga yaitu didalamnya terdapat beberapa buah sungai yang mana namanya adalah: al-Salsabill, alTasnim, al-Kafür. Adapun nikmat surga terdapat beberapa peringkat dan berdasarkan pada tahapan spiritual para penghuinya. Pertama: sebagian ahli surga mendapat nikmat surga yang melimpah melipu jasmani dan rohani, dan nikmat jasmani tersebut adalah seperti yang dirasakan didunia. Kedua sebagian ahli surga menikmati kesenangan karena surga adalah tempat kemuliaan yang dipilih oleh Allah SWT untuk mereka. Oleh karena itu, surga adalah tempat yang memperlihatkan keriḍaan Allah SWT yang dapat mendekatkan penghuninya kepadanya. ${ }^{49}$

Adapun nikmat surga yang dinyatakan adalah sebagai berikut:

a. Kebahagiaan terbesar yaitu berhasilnya memperoleh keriḍaan Allah SWT.

\footnotetext{
${ }^{45}$ Wahbah al-Zuhaili, al-Tafsïr al-Munïr, terj. AbdulHayyie, 493-494.

${ }^{46}$ Al-Qur'ān, 34: 430.

${ }^{47}$ Deddy Ilyas, “Antara surga dan neraka, 168

${ }^{48}$ Ibn Mandz\}ur, Lisān al'Arab, 440

${ }^{49}$ Deddy Ilyas, "Antara surga dan neraka, 169
} 
b. Kesenangan jasmani (seksual) karena setiap orang yang beriman mendapatkan tujuh puluh ribu bidadari selain dari istri mereka. Para bidadari itu senantiasa berada dalam keadaan suci setiap kali mereka dinginkan.

c. Makanan dan buah- buahan yang lezat pada setiap waktu dengan rasa yang baru. Hal ini susuai dengan keterangan al-Qur'ān: "setiap mereka diberi rezeki buah-buahan dalam surga-surga itu"."

d. Hati yang senantiasa gembira, bahagia dan tenang.

e. Berkumpul bersama dalam kegembiraan, sesuai dengan keterangan dalam al-Qur'ān: "dan kami lenyapkan segala rasa dendam yang berada dalam hati mereka, sedang mereka merasa bersaudara duduk berhadap-hadapan diatas dipan-dipan". 5.

f. Istana dan tempat tinggal yang dibuat dari logam yang berharga dan dihiasi dengan permata, kebun yang mengalir sungai didalamnya dan juga buah-buahan.

g. Berbagai bentuk kesenangan termasuk kicauan burung yang hanya diberikan pada orang yang memelihara diri mereka dari music didunia.

h. Sungai yang mengalir, termasuk sungai khamer yang disediakan dalam surga dan tidak memabukkan juga tidak memberikan efek apapun pada pancaindra maupun akhlak yang mana semua itu disediakan pada orang-orang yang menjauhi khamr semasa hidupnya di dunia.

i. Pengetahuan bahwa kebahagiaan surge hanya untuk mereka selamanya tanpa adanya rasa takut kepada kematian, perpindahan, kesakitan dan kebimbangan.

j. Keridhaan Allah SWT yang senantiasa berlipat ganda dan mereka senantiasa selalu ingat kepada Allah SWT. ${ }^{52}$

Dilihat dari interpretasi Ibn 'Arabì, beliau memaknai surga sebagai tempat yang kekal dan semuanya kekal didalamnya.Surga adalah gudang kenikmatan yang patut diperoleh oleh hamba yang taqwa kepada Allah SWT.Disamping itu beliau memaknai surga sebagai tempat kesenangan dan kebahagiaan yang membuat penghuni surga betah didalamnya.

${ }^{50}$ Al-Qur'ān, 2: 25.

${ }^{51}$ Al-Qur'ān, 15: 47.

${ }^{52}$ Deddy Ilyas, “Antara surga dan neraka, 170 
Tidak hanya itu, pengarang kitab al-Futuhàt al-Makkiyah ini menyebutkan dalam kitabnya bahwa surga itu dimaknai sebagai tempat yang dilengkapi dengan berbagai jamuan atau hidangan mulai dari makanan, minuman, pakaian, pengharum, nyanyian yang merdu dan raut wajah yang berseri- seri. Dan beliau juga memaknai surga sebagai sebuah tempat yang dilengkapi dengan pemandangan pohon yang rindang dan sungai yang mengalir jernih serta dipenuhi dengan bidadari. $^{53}$

\section{Makna neraka dalam al-Qur'ān}

Kata al-Nār bermakna api atau sesuatu yang membakar dan selalu menyala-nyalaserta dapat ditangkap oleh panca indera manusia. ${ }^{54} \mathrm{Hal}$ ini sesuai dengan keterangan dalam al-Qur'ān yang artinya"maka terangkanlah kepadaku tentang api yang kamu nyalakan(dengan menggosok gosokkan kayu). ${ }^{55} \mathrm{Kata}$ al-Năr juga berarti panas ${ }^{56}$. Dalam hal ini sesuai dengan keterangan al-Qur'ān yang artinya: "peliharalah dirimu dari neraka yang bahan bakarnya manusia dan batu, yang disediakan bagi orang-orang kafir. ${ }^{, 57}$

Dalam al-Qur'ān kata al-När ditemukan sebanyak 126 kali. Sebagaimana yang dapat dipahami secara ringkas dari tulisan Dr. Musthafa Murad, bahwa nabi Muhammad melihat selam perjalanan Isra' wa al-Mi'rāj siksa bagi para pendurhaka dan nikmat bagi orangorang yang taat. Itu berarti neraka menyediakan balasan penderitaan dan 'adhab kepada jasmani dan rohani manusia. ${ }^{58}$

Dengan demikian neraka merupakan tempat tinggal bagi orang-orang kafir dan munafiq dan juga melibatkan aspek jasmani dan rohani. Adapun penghuni neraka terdiri dari para pelaku maksiat dan kezaliman. Neraka digambarkan sebagai tempat yang penuh dengan kesengsaraan tampa kesudahan dan pengurangan. Ia disimpulkan sebagai tempat yang penuh dengan keburukan tanpa kebaikan sedikitpun didalamnya. ${ }^{59}$

Adapun neraka, Ibn 'Arabi memaknai sebagai tempat yang mana didalamnya masih disertai dengan kasih sayang Allah

\footnotetext{
${ }^{53}$ Muhyiddin Ibn 'Arabi, al-Futuhāt al-Makkiyah, 353.

${ }^{54}$ Deddy Ilyas, “Antara surga dan neraka, 171.

${ }^{55}$ Al-Qur'ān, 56: 71.

${ }^{56}$ Deddy Ilyas, “Antara surga, 171.

${ }^{57}$ Al-Qur'ān, 2: 24.

${ }^{58}$ Deddy Ilyas, “Antara surga dan neraka, 171.

${ }^{59}$ Ibid, 172.
} 
SWT.Oleh karena itu penghuni neraka diumpamakan dengan orang yang tidur dimana mereka tidak hidup dan tidak mati.Beliau juga berpendapat bahwa dineraka terdapat kesenangan atau kebahagiaan yang diumpamakan dengan orang yang bermimpi dalam tidurnya, hanya saja tidurnya tidak merubah tempat dimana dia berada, yaitu tetap didalam neraka.

Pertama tentang kasih sayang Allah SWT yang mana beliau memaknainya bahwa didalam neraka terdapat kasih sayang Allah SWT, sehingga penghuni neraka diumpamakan dengan orang yang tidur yang disertai dengan mimpi, itupun disebabkan adanya kasih sayang Allah SWT terhadap penghuni neraka.

Kedua tentang mimpi yang mana beliau meyebutkan bahwa mimpi yang dialami oleh penghuni neraka yaitu terkadang terlihat seperti orang yang tidur terbaring dengan keadaan yang sakit dan penuh keputus asaan, maka mimpi yang dihasilkannya pun dengan raut wajah yang menakitkan atau menyedihkan. Begitupun sebaliknya penghuni neraka terkadang terlihat seperti orang yang tidur dengan bermimpi dirinya bagaikan seorang raja yang mempunyai kekayaan dan kekuasaan, maka raut wajah yang dihasilkan yaitu dengan senyuman, tentu itu semua tidak lain bentuk kasih sayang Allah masih ada didalam neraka.

Ketiga yaitu tentang tempat tidur yang disertai mimpi yaitu beliau menetapkan bahwasannya tetap berda didalam neraka. Yang mana pengarang kitab al-Futhāt al-Makkiyah ini dalam kitabnya memaknai neraka sebagai penjara atau tahanan yang didalamnya menjadi sarag berbagai penyakit, dan beliau juga menyebutkan bahwa neraka dipenuhi dengan makanan yang terbuat dari hati hitamnya hewan yang hidup di gunung yang terbuat dari darah yang kental yang mengandung penyakit sehingga membuat ahli neraka merasa kesakitan.

\section{Makna surga dan neraka menurut Ibn 'Arabỉ}

Menurut Ibn 'Arabì surga itu adalah tempat yang kekal sebagaimana yang telah beliau jelaskan dalam kitabnya "Rahmatun min al-Rahmān, dan al-Futuhăt al-Makkiyah" dalam menafsirkan ayat sebagai berikut:

a. Surah al- Ra'd ayat 35

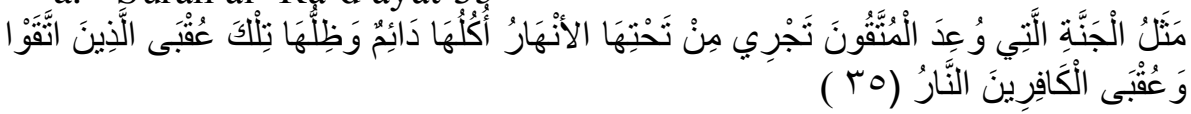


Artinya "perumpamaan syurga yang dijanjikan kepada orang-orang yang takwa ialah (seperti taman); mengalir sungai-sungai di dalamnya; buahnya tak henti-henti sedang naungannya (demikian pula). Itulah tempat kesudahan bagi orang-orang yang bertakwa, sedang tempat kesudahan bagi orang-orang kafir ialah neraka."(Q.S. al-Ra'd 13:35)

Dalam ayat ini Ibn 'Arabīmenafsirkan bahwa surga yang dijanjikan terhadap orang-orang yang bertakwa kepadanya. Surga yang dijanjikan yaitu surga yang didalamnya terdapat sungai-sungai yang mengalir dan juga terdapat makanan dan tempat teduh yang semua kekal adanya karena sesungguhnya akhirat itu tempat yang kekal dan didalam kekekalannya semua manusia makan dan tidak berpuasa, dan ahli surgapun sarapannya dengan berbagai sesuatu yang enak dan sarapan tersebut juga kekal dan makanannya pun juga kekal dan tidak terput us put us karena kekekalannya itu adalah sesuatu yang sangat nikmat. Makanan yang terdapat didalamnya sangat baik buat badan.Maka dari itu ahli surga makan dan minum, dan mereka makan dan minum bukan karena kelaparan melainkan karena syahwat.Karena sesungguhnya ahli surga mengetahuinya bahwa inilah saatnya kenikmatan yang patut diperoleh. ${ }^{60}$

Dalam kitabnya al-Futuhăt al-Makkiyah, Ibn 'Arabi memaknai bahwa surga adalah sebuah tempat kesenangan yang dilengkapi dengan makanan dan minuman, pernikahan, pakaian, pengharum, nyanyian yang merdu dan raut wajah yang berseri- seri. Dan surga dihuni oleh para bidadari cantik dan dikelilingi oleh rindangnya pepohonan dan berbagai sungai yang mengalir jernih. ${ }^{61}$

b. Surah al-'A'lā Ayat 12-13

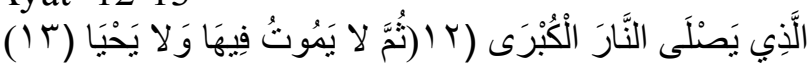

Artinya: "12. (yaitu) orang yang akan memasuki api yang besar (neraka), 13. kemudian Dia tidak akan mati di dalamnya dan tidak (pula) hidup."(Q.S. al-A'lā 87:12-13)

Dalam ayat ini Ibn 'Arabi memaknai bahwasannya keadaan ahli neraka atau penghuni neraka seperti halnya orang yang tidur dimana mereka tidak mati pula tidak hidup.ahli neraka juga mempunyai kesenananganseperti halnya orang yang sedang tidur dengan disertai oleh mimpi tapi Ibn 'Arabìmenyebutkan bahwasanya

${ }^{60}$ Muhyiddin Ibn 'Arabi, Raḥmatun min al-Raḥmān fí Tafsīiri wa Isyārat al Qur'ān,424.

${ }^{61}$ Muhyiddin Ibn 'Arabì, al-Futuhàt al-Makkiyah, 353. 
kenikmatan yang dialami tersebut yaitu tetap berada di dalam neraka. Ahli neraka tidak bangun-bangun dari tidurnya maka munurut Ibn'Arabiitulah bentuk dari kasih sayang Allah terhadap ahli neraka. ${ }^{62}$

Dalam kitabnya "al-Futuhāt al-Makkiyah" Ibn "Arabì menjelaskan bahwa makna neraka adalah tempat bersarangnya penyakit dan penuh dengan kesusahan, neraka juga dimaknai dengan tahanan Allah SWT. ${ }^{63}$

Ibn 'Arabi membagi neraka menjadi dua kategori yaitu Nār Allāh (Neraka Allah) yang berarti neraka yang bersifat batin atau neraka yang berada dalam diri seseorang yang menjadi pusat terjadinya pembakaran, Ibn 'Arabi juga menyebut dengan neraka yang satu yaitu neraka yang senantiasa mengiringi keberadaan setiap orang, menurut Ibn 'Arabi neraka ini tidak dinyalakan oleh bahan bakar berupa manusia yang ingkar dan bebatuan yang dijadikan sembahan melainkan Nār Allāh menurut beliau adalah yang membakar itu diakibatkan oleh amal perbuatan hati seseorang seperti kekufuran dan kemunafikan. Yang kedua adalahNār Al-Lahab (Neraka yang menyala- nyala) yaitu jenis neraka yang berbeda dari $N \overline{a r}$ Allāh yang disebutkan di atas.Perbedaan itu tampak dalam tiga aspek berikut, yaitu penisbahan, sifat dan amalan yang menyebabkan neraka menyala.

Ditinjau dari aspek pertama, Nār al-Lahab adalah neraka yang dinisbahkan kepada selain allah. Ibn Arabimenyebutnyadengan neraka yang memiliki bahan bakar dengan daya api yang menyalanyala, melingkar dan menyambar-nyambar seperti neraka jahannam.

Aspek yang kedua yaitu terletak pada sifatnya yang zahir, yaitu di luar batin manusia. Maksudnya, ini neraka yang nanti manusia akan dimasukkan ke dalamnya sebagai balasan atas kekufuran, kemungkaran dan kedzoliman yang telah dilakukan selama hidupnya.Ini sepenuhnya berbeda dari Nār Allāh yang bersifat batin, yang justeru diletakkan Allah SWT dalam hati seseorang.

Aspek yang terakhir yaitu bahwasanya neraka ini tidak akan menyala mekainkan karena keburukan amal seseorang, yaitu setiap bentuk perbuatan lahiriah yang dikategorikan syariat sebagai perbuatan dosa. Contohnya seperti perbuatan-perbuatan yang kasat mata seperti zina, fitnah, gibah, membunuh, menghasut, mencuri,

${ }^{62}$ Muhyiddin Ibn 'Arabī, Rahmmatun min al-Rahmmān, 485.

${ }^{63}$ Muhyiddin Ibn 'Arabì, al-Futuhāat al-Makkiyah, 353. 
menghina dan lain sebagainya.Di sini faktor kelahiriahan amal-amal tersebut mendapat penekanan yang serius agarberbeda dari amalan negatif yang bersifat batin yang menjadi pemicu menyalanya Nār Allăh yang telah disebutkan sebelumnya, seperti buruk sangka, denki, ingkar dan lain sebagainya. ${ }^{64}$

Dilihat dari semua aspek uraian di atas tentang surga dan neraka bahwasanya interpretasi Ibn 'Arabi tidaklah jauh berbeda dari penafsiran para mufassir pada umumnya, hanya saja dalam pola nalar berfikirnya yang berbeda.

Dengan demikian maka jelaslah neraka itu adalah tempat dimana semua orang tidak menyukainya karena tempat itu penuh dengan penyakit dan kesusahan, dan neraka menjadi tahanan bagi orang- orang yang tidak taqwa kepada Allah SWT, dan bagi orangorang yang ingkar kepadanya.

\section{Epilog}

Berdasarkan uraian di atas maka dapat disimpulkan sebagai berikut:

1. Penafsiran Ibn 'Arabì terhadap Q.S al-Ra'd ayat 35 dan al-A'lā ayat 12-13 maka dapat disimpulkan bahwa makna surga adalah sebuah rumah kenikmatan yang semuanya kekal didalamnya, ahli surgapun biasa diumpamakan dengan orang yang berbuka puasa dimana mereka tahu bahwa pada saat itu sudah saatnya menikmati semua hidangan yang tersedia dengan shahwatnya. Surga itu dipenuhi dengan makanan, minuman, pernikahan, pakaian, pengharum, nyanyian yang merdu dan raut wajah yang berseri-seri dengan pemandangan yang dipenuhi dengan bidadari dan dikelilingi ridangnya pepohonan dan sungai yang mengalir jernih. Sedangkan Neraka Ibn 'Arabì memaknai bahwasannya keadaan ahli neraka atau penghuni neraka seperti halnya orang yang tidur dimana mereka tidak mati pula tidak hidup.ahli neraka juga mempunyai kesenanangan seperti halnya orang yang sedang tidur dengan disertai oleh mimpi tapi Ibn 'Arabi menyebutkan bahwasanya kenikmatan yang dialami tersebut yaitu tetap berada di dalam neraka. Ahli neraka tidak bangun-bangun dari tidurnya maka munurut Ibn 'Arabī itulah bentuk dari kasih sayang allah SWT terhadap ahli neraka. Dalam hal ini Ibn 'Arabi

\footnotetext{
${ }^{64}$ Iskandar Arnel dan Muhammad Yasir, "Urgensi Al-Nār dalam Perspektif Tashawuf Ibn 'Arabi dalam kehidupan Insān.”, 93.
} 
mengumpamakan terhadap ahli neraka yaitu seperti halnya orang yang sedang kepanasan dan diberi sesuatu yang sangat dingin.

2. Makna surga dan neraka menurut Ibn 'Arabī

Makna surga adalah tempat yang kekal dan semuanya kekal didalamnya. Surga adalah gudang kenikmatan yang patut diperoleh oleh hamba yang taqwa kepada Allah SWT. Disamping itu beliau memaknai surga sebagai tempat kesenangan dan kebahagiaan yang membuat penghuni surga betah didalamnya.Tidak hanya itu, surga itu dimaknai sebagai tempat yang dilengkapi dengan berbagai jamuan atau hidangan mulai dari makanan, minuman, pakaian, pengharum, nyanyian yang merdu, raut wajah yang berseri- seri dan dilengkapi dengan pemandangan pohon yang rindang dan sungai yang mengalir jernih serta dipenuhi dengan bidadari.

Makna neraka adalah tempat yang mana didalamnya masih disertai dengan kasih sayang Allah SWT. Oleh karena itu penghuni neraka diumpamakan dengan orang yang tidur dimana mereka tidak hidup dan tidak mati. Beliau juga berpendapat bahwa dineraka terdapat kesenangan atau kebahagiaan yang diumpamakan dengan orang yang bermimpi dalam tidurnya, hanya saja tidurnya tidak merubah tempat dimana dia berada, yaitu tetap didalam neraka.

\section{Daftar Pustaka}

Agama, Departemen RI. al-Qur'ān dan Terjemahannya. Jakarta : Departemen Agama RI, 2004.

Arnel, Iskandar dan Muhammad Yasir. "Urgensi al-Nār dalam perspektif tashawuf Ibn 'Arabi dalam kehidupan insan.”, Jurnal usuluddin, 23, Juni, 2015.

Damyati, Akhmad Rofii, dkk, "El-Furqania jurnal Ushuluddin dan Ilmu-Ilmu keislaman.”,STIU :A1-Mujtama’ Pamekasan, Vol. 001, No. 01, Agustus, 2015.

Fajri, Em Zul dan Ratu Aprilia Senja.Kamus Lengkap Bahasa Indonesia.Aneka Ilmu Difa Publisher, 2002.

Fayumi (al) Muhammad Ibrahim.Ibn 'Arabi(minyingkap kode dan menguak symbol dibalik faham Wihdat al-Wujüd).kairo: Erlangga, 2007.

Hakim, ManshurAbdul .Kiamat.Jakarta:Gema insani. 2006.

Hamka.Juz 'Amma Tafsìr al-Azhär. Jakarta: Gema Insani, 2015. 
Ibn 'Arabi, Muhyiddin .al-Futuhăat al-Makkiyah. University of Toronto library, 1852.

Ibn 'Arabi,Muhyiddin Rahmatun min al-Rahmān fí Tafsìi wa Isyārati al-Qur'ān.Kairo: Dār al-Kutūb al-Ilmiyah,1989.

Ibn Muhammad, Hasin .Kamus al-Qur'ān au Islāh al- Wujūh wa alNaḍair fí al-Qur'ān al-Karim.Bairut: Darul 'Ilmi, 1085.

Ilyas, Deddy. "Antara surga dan neraka menanti kehidupan.",2, Desember, 2013.

Kathir, Ibnu.lubāb al-Tafsir min ibn kathïr, terj. M.Abdul Gaffar. Jakarta: pustaka imam asy-syafi' I, 2008.

Manzur, Ibn. Lisān al Arab.Beirut: Dar al-'arif,1119.

Marhan, S. Royani .Kiamat dan Akhirat. Jakarta: Erlangga, 2001.

Nasir, Ridlwan. memahami al-Qur'ān "perspektif metodologi tafsir muqarin”. Surabaya: cv. Indra media, 2003.

Qurtubi (al).Al-jāmi' li ahkām al-Qur'ān, terj.Muhyiddin masridha. Jakarta: pustaka azzam, 2008.

Rohman (al) Abd, Sayyid .Durūs al- Aqāid al-Diniati, terj. Abd alMajīd Tamīm. Maktabah shaīh Sālim bin Sa'ad Nabhān, TTh.

Solihin, M dan Rosihon Anwar.Ilmu Tasawuf. bandung: Pustaka Setia, 2003.

Tabari (al)Jāmi' al-Bayān an Ta'wīl ay al-Qur'ān, terj. Misbah. Jakarta: pustaka azzam, 2009.

W. Alhafidz, Ahsin.Kamus Ilmu Al-Qur'ān. Jakarta: amzah, 2008.

Zuhaili (al) Wahbah . Al-Tafsir al-Munir. Jakarta: Gema Insani, 2015. 